\title{
Essential Oil Content, Antioxidative Characteristics and Enzyme Inhibitory Activity of Sideritis akmanii Aytaç, Ekici \& Dönmez
}

\author{
Sideritis akmanii Aytaç, Ekici \& Dönmez Uçucu Yağ İçeriği, Antioksidatif \\ Özellikleri ve Enzim İnhibitör Aktivitesi
}

\author{
(D) Laçine AKSOY, (D) İsmail GÜZEY, (D) Mürüvvet DÜZ* \\ Afyon Kocatepe University, Faculty of Science and Arts, Department of Chemistry, Afyonkarahisar, Turkey
}

\begin{abstract}
Objectives: Our research measures the essential oil analysis mineral substance profiles, total phenolic substance content, free radical scavenger properties, antioxidant capacity, and enzyme inhibitory activity of Sideritis akmanii Aytaç, Ekici \& Dönmez, 1996.

Materials and Methods: A mixture of S. akmanii plant roots and stems were used. Essential fatty acid components of S. akmanii were determined by gas chromatography-mass spectrometry and bioelement concentrations by inductively coupled plasma optical emission spectrometry. The antioxidant activity of extracts was screened by 2,2-diphenyl-1-picrylhydrazyl (DPPH) radical scavenging activities, total phenolic content, total antioxidant status (TAS), total oxidant status (TOS) analysis. Cholinesterase (ChE), $\alpha$-glucosidase, $\alpha$-amylase, and tyrosinase inhibitory activity was determined.

Results: The results demonstrated that the phenolic substance content was higher in methanol extract $(144.08 \pm 2.01 \mu \mathrm{g}$ gallic acid equivalent/mg extract). DPPH scavenging effect of S. akmanii methanol extract (73.2\%) was higher than acetone extract (60.1\%). TAS values of extract methanol and acetone were $2.32 \pm 0.4$ and $2.38 \pm 0.2 \mu \mathrm{mol}$ trolox Eq/g, TOS values were $4.88 \pm 0.6$ and $5.04 \pm 0.5 \mu \mathrm{mol} \mathrm{H}_{2} \mathrm{O}_{2}$ Eq/g, and oxidative stress index values were $2.1 \pm 0.3$ and $2.11 \pm 0.24$ arbitrary units, respectively. Hexadecanoic acid (17.9\%) was found as the main component in the plant essential oil. S. akmanii species was prominent with high $\mathrm{Mg}$ and Al concentrations. Anti-ChE activity was determined that acetone extract (42.95\% \pm 0.90 ; $217.37 \pm 0.81 \mathrm{mg}$ galantamine equivalents [(GALAEs)/g] exhibited higher than methanol $(33.33 \% \pm 1.81 ; 208.76 \pm 1.62 \mathrm{mg}$ GALAE/g). $\alpha$-Amylase inhibition was high in methanol extract $[53.62 \pm 1.85 \mathrm{mmol}$ angiotensin converting enzymes (ACEs)/g extract] compared to acetone $(47.73 \pm 0.92 \mathrm{mmol}$ ACEs $/ \mathrm{g}$ extract). The tyrosinase inhibitory activity of S. akmanii was determined very low inhibition of the reference compound.

Conclusion: It has been determined that S. akmanii Aytaç, Ekici \& Dönmez extracts have antioxidant properties and can inhibit acetylcholinesterase, $\alpha$-glucosidase, $\alpha$-amylase enzymes. This study is informative on future studies on $S$. akmanii a highly bioavailable species and very extensive studies should be carried out.
\end{abstract}

Key words: Sideritis akmanii Aytaç, Ekici \& Dönmez, antioxidative activity, bioelement, essential oil, enzyme inhibitory activity

ÖZ

Amaç: Çalışmamız Sideritis akmanii Aytaç, Ekici ve Dönmez, 1996'nın antioksidan kapasitesini, toplam fenolik madde içeriğini, serbest radikal temizleyici özelliklerini, mineral madde profillerini, enzim inhibitör aktivitesini ve uçucu yağ analizini belirlenmiștir.

Gereç ve Yöntemler: S. akmanii bitki kökleri ve saplarından oluşan bir karışım kullanılmıştır. Bitkinin temel yağ asidi bileșenleri gaz kromatografisikütle spektrometresi ve bioelement konsantrasyonları indüktif eşleşmiş plazma optik emisyon spektrometresi ile belirlenmiştir. Metanol ve aseton ekstresinin antioksidan aktivitesi, 2,2-difenil-1-pikrilhidrazil radikali süpürücü etkisi, toplam fenolik içerik, toplam antioksidan durumu (TAS), toplam oksidan durumu (TOS) analizi ile incelenmiștir. Kolinesteraz (ChE), $\alpha$-amilaz, $\alpha$-glukozidaz, tirozinaz inhibitör aktivitesi belirlenmiștir.

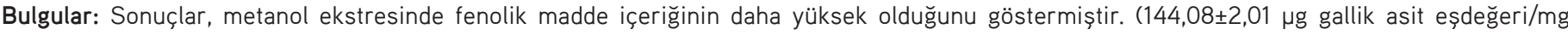
ekstre). S. akmanii metanol ekstresinin radikal süpürücü etkisi $(\% 73,2)$ aseton ekstresinden $(\% 60,1)$ daha yüksek bulunmuștur. Metanol ve aseton

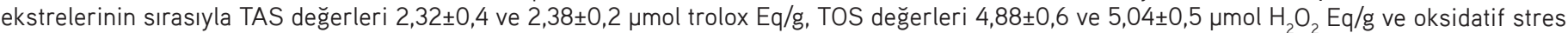

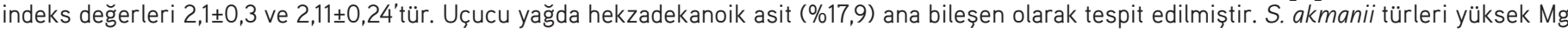


ve Al konsantrasyonları ile öne çıkmıştır. Anti-ChE aktivitesi, aseton ekstresinin ( $\% 42,95 \pm 0,90 ; 217,37 \pm 0,81$ mg GALAEs/g) metanol ekstresinden

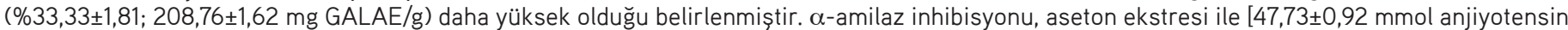
dönüştürücü enzim (ACE/g) ekstre] karşılaştırıldığında metanol ekstresinde $(53,62 \pm 1,85$ mmol ACE/g ekstre) daha yüksek tespit edilmiştir. S. akmanii'nin tirozinaz inhibe edici aktivitesi, referans bileșiğe göre çok düşük inhibisyon gösterdiği belirlenmiştir.

Sonuç: S. akmanii ekstrelerinin antioksidan özelliklere sahip olduğu ve asetilkolineesteraz, $\alpha$-glukozidaz, $\alpha$-amilaz enzimlerini inhibe edebildiği tespit edilmiştir. Bu çalışma, biyoyararlanımı yüksek bir tür olan S. akmanii ile ilgili gelecekte yapılacak çalışmalar hakkında bilgilendirici nitelikte olup, hücre kültürü ve hayvan deneylerini içeren çok kapsamlı çalışmaların yapılması gerekmektedir.

Anahtar kelimeler: Sideritis akmanii Aytaç, Ekici \& Dönmez, antioksidatif aktivite, bioelement, uçucu yağ, enzim inhibitör aktivite

\section{INTRODUCTION}

Sideritis akmanii Aytaç, Ekici \& Dönmez is an aromatic herbaceous plant with light green leafs and can grow up to 1 meter high. On the top, there are mucronate leaves and the leaves are $0.5 \mathrm{~mm}$ thick with a yellowish color. Sideritis species commonly known as mountain tea and clary has been used since ancient times in medicine due to their antibacterial, antifungal, antiviral, antiseptic, analgesic, antispasmodic, carminative, and antidiabetic properties. It is not exported and mostly used in the domestic market in Turkey. It is an endangered species due to its use in grazing and gathering in large quantities for animal feed production. Thus, the preservation and culturing of this economically significant species is necessary.

The enzyme inhibition theory is very popular in the treatment strategies for universal health problems such as diabetes and Alzheimer's. According to this theory, the key enzymes that affect the pathology of diseases are inhibited to alleviate symptoms caused by disease. ${ }^{2} \alpha$-Amylase and $\alpha$-glucosidase enzymes are the main enzymes of sugar metabolism and their activity increases blood glucose level. In this sense, inhibition of these enzymes is an important mechanism in the control of blood glucose level in diabetes. ${ }^{3}$ Tyrosinase is an oxidase that is the rate-limiting enzyme for controlling the production of melanin and the inhibition of this enzyme is the main way of controlling skin diseases. ${ }^{4}$ Acetylcholine esterase catalyzes the breakdown of acetyl and choline in the synaptic space. Increased cognitive functions by inhibiting this enzyme in Alzheimer's patients and this are called a cholinergic hypothesis. ${ }^{5}$

This study determined determine the essential oil analysis mineral substance profiles, total phenolic substance content, free radical scavenger properties, antioxidant capacity, and enzyme inhibitory activity of methanol and acetone extracts of S. akmanii collected at Kumalar Mountain in Afyon province in Turkey.

\section{MATERIALS AND METHODS}

\section{Plant material}

S. akmanii was collected at $1880 \mathrm{~m}$ altitude at Kumalar Mountain, Çakmaktepe Pass, Şuhut/Afyonkarahisar (37 T 0719245, UTM 4511056) in August 2015, and it was identified by Dr. Mustafa Kargıoğlu. The samples of the plant locally known as "tail tea" are stored at Afyon Kocatepe University, Faculty of Sciences and Literature herbarium.

\section{Preparation of extracts}

A mixture of $S$. akmanii roots and stems were used. These parts were crushed into small pieces and dried at ambient temperature in the shade. To prepare the extracts, $20 \mathrm{~g} \mathrm{~S}$. akmanii powder was mixed with $400 \mathrm{~mL}$ solvent. ${ }^{6}$ Extracts were used to determine free radical scavenging activity and total phenolic content. For the antioxidant status analysis, $1 \mathrm{~g}$ dried and pulverized plant was sonicated after adding $10 \mathrm{~mL}$ solvent. The product was then filtered through paper and centrifuged. The obtained supernatant was centrifuged again for use in the analyses. ${ }^{7}$ To determine S. akmanii mineral substance content, $0.5 \mathrm{~g}$ dried and pulverized plant was placed in a microwave to decompose the organic components. ${ }^{8}$ Preparation of plant ethanol extracts for enzyme inhibition analysis was prepared at $100 \mu \mathrm{g} / \mathrm{mL}$ concentration. Acetone and methanol extracts were prepared by dissolving in ethanol for enzyme inhibition analyzes. $10 \mathrm{mg}(0.01 \mathrm{~g})$ of the extract was first dissolved in $1 \mathrm{~mL}$ ethanol and a $10 \mathrm{mg} / \mathrm{mL}$ stock was prepared. $100 \mu \mathrm{g} / \mathrm{mL}$ extracts were prepared from stock material.

\section{Isolation of essential oil}

For the extraction of essential oils from $S$. akmanii by hydrodistillation using a Clevenger type apparatus in $2.5 \mathrm{~h}$. At the end of the distillation, the essential oil was collected, dried under anhydrous $\mathrm{Na}_{2} \mathrm{SO}_{4}$ and stored at $4^{\circ} \mathrm{C}$ in the dark until analysis.

\section{Determination of 2,2-diphenyl-1-picrylhydrazyl (DPPH) radical scavenging activity}

The DPPH radical scavenging activities of methanol and acetone extracts from root and stem parts of $S$. akmanii species were determined by the Blois ${ }^{9}$ method. DPPH was used as free radical. Ethanol was added to samples at concentrations of 45,90 , and $135 \mu \mathrm{g} / \mathrm{mL}$. Stock DPPH was added to the samples and allowed to incubate for $30 \mathrm{~min}$ in the dark and at room temperature. Absorbance measurements were recorded at 517 $\mathrm{nm}$ against ethanol blank.

\section{Determination of total phenolic content}

Total phenolic content of the extracts was determined using the Folin-Ciocalteu method. Folin-Ciocalteu reagent was added to the plant extracts and standard antioxidant solutions. Samples were stored in room for $2 \mathrm{~h}$ with the addition of $\mathrm{Na}_{2} \mathrm{CO}_{3}$. Absorbance measured against water at $760 \mathrm{~nm} .{ }^{10}$ The graph was plotted using the gallic acid standard. The total number of phenolic compounds in both extracts was calculated as gallic acid equivalent (GAE) using the formula obtained from the 
graph $\left(r^{2}: 0.9881\right)$. The standard gallic acid graph developed for this purpose is presented in Figure 1.

Total antioxidant status (TAS), total oxidant status (TOS) and oxidative stress index values (OSI)

Total antioxidant and TOS of S. akmanii was measured using commercial kits (Rel Assay, Gaziantep, Turkey). ${ }^{7}$ The OSI index as an indicator of oxidative stress was calculated by dividing the TOS by the TAS.

\section{Determination of the mineral substance content}

A microwave oven (Speed Wave ERGHOF) was used to deform the organic compounds in the samples. Inductively coupled plasma-optical emission spectrometry (Spectro Genesis) bioelement concentrations were measured after the samples were ready for analysis. ${ }^{8}$

Gas chromatography-mass spectrometry (GC-MS) analysis Volatile components in the $1 \mathrm{~mL}$ sample injected into the system were determined on the GC-MS device. The analysis conditions of the device are given in Table 1.

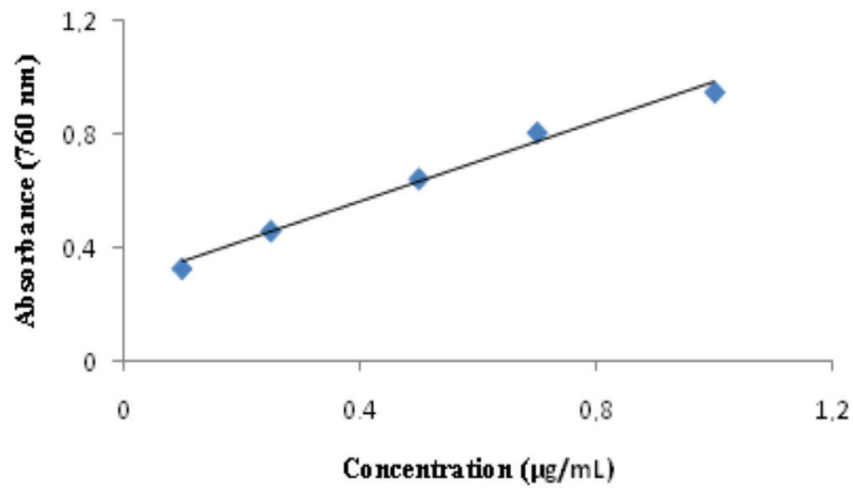

Figure 1. Gallic acid standard curves

Table 1. GC-MS analysis conditions

\begin{tabular}{ll}
\hline Features & Description \\
\hline System & $\begin{array}{l}\text { Agilent 7890 B GC5977B mass } \\
\text { selective dedector system }\end{array}$ \\
\hline Column & $\begin{array}{l}\text { Agilent HP-Innowax (60 m, } 0.25 \\
\text { mm inner diameter, } 0.25 \mathrm{~m} \text { film } \\
\text { thickness })\end{array}$ \\
\hline Injection temperature & $250^{\circ} \mathrm{C}$ \\
\hline lon source temperature & $230^{\circ} \mathrm{C}$ \\
\hline lonization mode hand & $\mathrm{E} 1$ \\
\hline Electron energy & 70 ev \\
\hline Mass range & $35-450 \mathrm{~m} / \mathrm{z}$ \\
\hline The temperature program & $\begin{array}{l}60^{\circ} \mathrm{C}(10 \mathrm{~min}), 4^{\circ} \mathrm{C} / \mathrm{min} 220^{\circ} \mathrm{C}(10 \\
\mathrm{min}) 1^{\circ} \mathrm{C} / \mathrm{min} 240^{\circ} \mathrm{C}(20 \mathrm{~min})\end{array}$ \\
\hline Carrier gas & Helium $(0.7 \mathrm{~mL} / \mathrm{min})$ \\
\hline Definitions spectral database & Wiley $9-\mathrm{nist} 11 \mathrm{nass}$ \\
\hline
\end{tabular}

GC-MS: Gas chromatography-mass spectrometry

\section{Enzyme inhibitory activity}

Ellman method was used to determine the cholinesterase (ChE) inhibitory activity of the extracts and in a 96-well microplate using ELISA reader." Sample solution $(100 \mu \mathrm{g} / \mathrm{mL}, 50 \mu \mathrm{L})$ was mixed with DTNB $(0,3 \mathrm{mM}, 125 \mu \mathrm{L})$ and acetyl choline esterase (AChE) solution $(0,026 \mathrm{U} / \mathrm{mL}, 25 \mu \mathrm{L})$ in Tris- $\mathrm{HCl}$ buffer $(\mathrm{pH}$ : 8.0) in a 96-well microplate and incubated for $15 \mathrm{~min}$ at $25^{\circ} \mathrm{C}$. The reaction was initiated by the addition of $1.5 \mathrm{mM} 25 \mu \mathrm{L}$ of acetyl thio quinoline iodide substrate. Similarly, enzyme-free tube was prepared as a blank. Control sample for \% inhibition calculation was prepared by the addition of ethanol instead of the sample. Sample, control, and blank absorbances were read at $405 \mathrm{~nm}$ after incubation at $25^{\circ} \mathrm{C}$ for $10 \mathrm{~min}$. Galantamine was used as standard. Standard sample solutions of 0.5-0.0005 $\mu \mathrm{mol} / \mathrm{mL}$ were prepared and the calibration graph is plotted. Results was expressed both equivalents of galanthamine (mg GALAEs/g extract) and \% inhibition value. Equality is given below to calculate the percent inhibition value.

$\% I=\left(A_{\text {control }}-A_{\text {sample }}\right) / A_{\text {control }} \times 100$

$A_{\text {control }}$ : Absorption obtained by adding solvent used instead of plant extract

$A_{\text {sample }}$ : absorbance of plant extract

$\alpha$-amylase inhibitory activity was performed using CarawaySomogyi iodide/potassium iodide (IKI) method. ${ }^{12}$ Sample solution at $100 \mu \mathrm{g} / \mathrm{mL}$ concentration $(25 \mu \mathrm{L})$ was mixed with $\alpha$-amylase solution $(50 \mu \mathrm{L})$ in phosphate buffer $(\mathrm{pH} 6.9$ with $6 \mathrm{mM}$ sodium chloride) in a 96-well microplate and incubated for $10 \mathrm{~min}$ at $37^{\circ} \mathrm{C}$. After the pre-incubation, the reaction was started by adding $50 \mu \mathrm{L}$ of $0.05 \%$ starch solution. Similarly, the enzyme-free blank solution and control samples containing solvent were prepared instead of samples. The reaction was stopped by the addition of $\mathrm{HCl}(25 \mu \mathrm{L}, 1 \mathrm{M})$ and IKI solution (100 $\mu \mathrm{L}$ ) was added. Acarbose was used as standard material.

Standard sample solutions of $2 \mu \mathrm{mol} / \mathrm{mL}, 1 \mu \mathrm{mol} / \mathrm{mL}, 0.1$ $\mu \mathrm{mol} / \mathrm{mL}, 0.01 \mu \mathrm{mol} / \mathrm{mL}$, and $0.001 \mu \mathrm{mol} / \mathrm{mL}$ were prepared and a calibration graph was drawn. The results of $\alpha$-amylase inhibitory activity were expressed as equivalent to both acarbose equivalent ( $\mathrm{mmol} A K A E / g$ ) and the $\%$ inhibition value used for the calculation.

$\alpha$-Glucosidase inhibitory activity was performed according to the method. ${ }^{13}$ Sample solution $(100 \mu \mathrm{g} / \mathrm{mL}$ extracts, $50 \mu \mathrm{L})$ was mixed with glutathione ( $2 \mathrm{mg} / \mathrm{mL}, 50 \mu \mathrm{L}$ ), $\alpha$-glucosidase solution $(2 \mu / \mathrm{mL}, 50 \mu \mathrm{L})$ in phosphate buffer ( $\mathrm{pH}$ 6.8) and 4-nitrofenil $\beta$-D-glukuronid (10 mM, $50 \mu \mathrm{L}$ ) in a 96-well microplate. Similarly, enzyme-free blank solution and control samples containing solvent instead of the sample were prepared. The reaction was stopped by adding $50 \mu \mathrm{L}$ of $0.2 \mathrm{M} \mathrm{Na}_{2} \mathrm{CO}_{3}$ after incubating for $15 \mathrm{~min}$ at $37^{\circ} \mathrm{C}$. Results was expressed to both acarbose ( $\mathrm{mmol} A K A E / g$ ) and the \% inhibition value.

Dopacrome method modified with L-3.4-dihydroxyphenylalanine (L-DOPA) as substrate was used for determination of tyrosinase inhibitory activity. ${ }^{14}$ Extracts were dissolved in 50\% dimethyl sulfoxide and prepared at a concentration of $100 \mu \mathrm{g} /$ $\mathrm{mL}$. $40 \mu \mathrm{L}$ of the sample solution, $20 \mu \mathrm{L}$ of $480 \mu / \mathrm{mL}$ tyrosinase enzyme solution and $120 \mu \mathrm{L}$ of phosphate buffer $(20 \mathrm{mM} \mathrm{pH} 6.8$ 
sodium phosphate buffer) were mixed in a 96-well microplate and incubated at $25^{\circ} \mathrm{C}$ for $15 \mathrm{~min}$. The reaction was initiated by addition of $20 \mu \mathrm{L}$ of $2.5 \mathrm{mM} \mathrm{L-DOPA}$. Control sample for $\%$ inhibition calculation prepared by the addition of ethanol instead of the sample. Samples and blank absorbances were read at $492 \mathrm{~nm}$. Results are expressed as equivalent to both kojic acid (mg KAE/g) and \% inhibition value.

\section{Statistical analysis}

The mean of four separate analysis results were presented as analysis results. The statistical analysis was performed using the software SPSS 15.0 (SPSS Inc.) and findings were recorded as mean \pm standard deviation.

\section{RESULTS AND DISCUSSION}

S. akmanii is a perennial species that grows at $1520-1550 \mathrm{~m}$ high steppes. The species flowers in July and August. It is collected to Kumalar Mountains in Afyonkarahisar province. S. akmanii species is in the endangered species category due to overgrazing and consumption as herbal tea.

\section{Total phenolic substance content}

Phenolic compounds had anti-oxidative, free radical scavenging, enzymatic activity regulating, cell proliferation inhibitive, anti-inflammatory properties in previous studies. ${ }^{15}$ Sideritis species are also a rich source of flavonoids. Major flavonoids found in Sideritis species were flavones, methoxyflavones, sideroflavones, cirsiliol and xanthomycin. Phytochemical studies on S. akmanii species reported sideridiol, sideroxol, linearol, isolinearol, folanol, and isofiolol content. ${ }^{16,17}$

The total phenolic content in the plants used in the study is presented in Table 2. As observed in Table 2, it was determined that $S$. akmanii plant methanol and acetone extract phenolic compound content was $144.08 \pm 2.01$ and $117.72 \pm 6.4 \mu \mathrm{g}$ GAE. We observed that the phenolic compounds in the plant and solvents used in the determination of antioxidant activity led to different results. It was found that the plant acetone extract contained higher phenolic compound levels compared to the methanol extract. This finding also provides information on higher antioxidant capacity due to the higher phenolic content of the species due to the procedures that would be conducted with an adequate solvent.

\section{$D P P H$ radical scavenging activity}

The DPPH method is often used to determine radical scavenging activities of plants. There are also studies conducted with Sideritis species in the literature. A comprehensive study that all Sideritis species had high antioxidant and DDPH radical scavenging properties due to their high phenolic substance

$\begin{array}{lcc}\begin{array}{l}\text { Table } 2 \text {. Total phenolic compound content in } 1 \mathrm{mg} \text { S. akmanii } \\ \text { methanol and acetone extracts }\end{array} & \text { SAM } & \text { SAA } \\ \begin{array}{lll}\text { Extract } & 144.08 \pm 2.01 & 117.72 \pm 6.4 \\ \hline \begin{array}{l}\text { Total phenolic compound content } \\ \text { ( } \mu \mathrm{g} \text { GAE/mg extract) }\end{array} & & \\ \hline\end{array}\end{array}$

The results are presented as mean \pm SD $(n=4)$. SAM: Sideritis akmanii methanol extract, SAA: Sideritis akmanii acetone extract content. $^{18}$ Sideritis caesarea, which has a higher total phenolic substance and flavonol content, had DPPH radical scavenging properties. ${ }^{19}$ In previous studies, it was determined that the high radical scavenging effect of methanol extracts was associated with the total amount of phenolic substance content in methanol extracts. Similarly, in this study, it was found that the radical scavenging properties of this extract were higher due to its high phenolic content.

DPPH radical scavenging activities of S. akmanii methanol and acetone extracts are presented in Figure 2. We observed that the DPPH radical scavenging activities of the extracts increased with the concentration. The DPPH radical scavenging activities of S. akmanii methanol and acetone extracts and the synthetic antioxidant butylated hydroxytoluene (BHT) and $\alpha$-tocopherol and $135 \mu \mathrm{g} / \mathrm{L}$ concentration of the natural antioxidant $\alpha$-tocopherol were determined as follows: $\alpha$-Tocopherol $>S$. akmanii methanol extract (SAM) BHT >S. akmanii acetone extract (SAA). The DPPH radical scavenging activities of S. akmanii methanol and acetone extracts were $78.7 \%$ in $\alpha$-tocopherol, $73.2 \%$ in methanol extract, $72.7 \%$ in BHT and $60.1 \%$ in acetone extract. Results suggested that the SAM had similar activities with BHT.

\section{TAS, TOS and OSI values}

There are several methods to determine the total antioxidant activities in plant extracts or active substances isolated from plants. ${ }^{20}$ Solitary measurement of antioxidants requires time consuming, expensive and complex techniques. For this reason, total antioxidant capacity or TAS measurement is the currently preferred and widely used methodology. TAS; TOS and OSI values for $S$. akmanii plant methanol and acetone extracts are presented in Figure 3. It was determined that $S$. akmanii plant methanol and acetone extract TAS values were $2.32 \pm 0.4$ and $2.38 \pm 0.2 \mu \mathrm{mol}$ trolox $\mathrm{Eq} / \mathrm{g}$, TOS values were $4.88 \pm 0.6$ and $5.04 \pm 0.5 \mu \mathrm{mol} \mathrm{H}_{2} \mathrm{O}_{2} \mathrm{Eq} / \mathrm{g}$, and $\mathrm{OSI}$ values were $2.1 \pm 0.3$ and $2.11 \pm 0.24$ arbitrary units, respectively. These results demonstrated that TAS values were similar in both plant

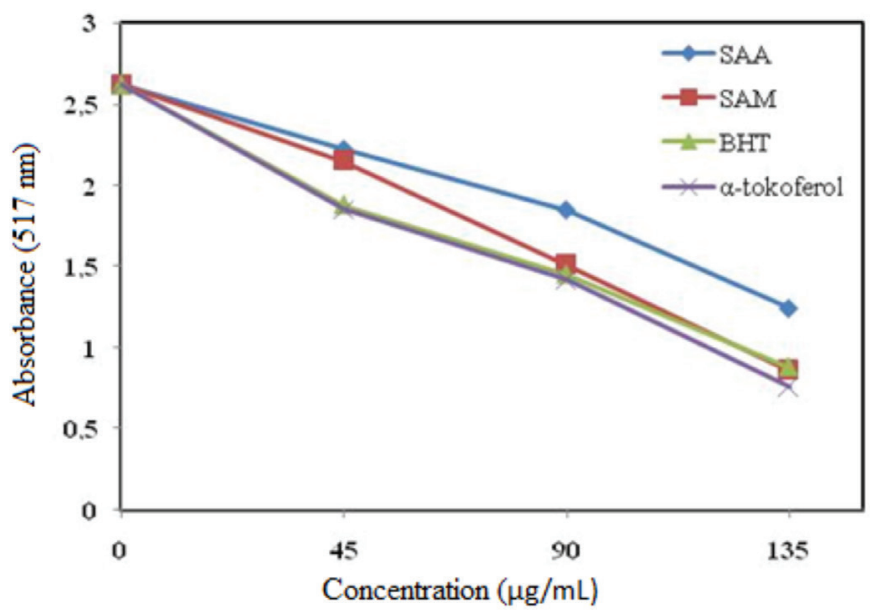

Figure 2. DPPH radical scavenging activities of plant extracts in different concentrations $(45-135 \mu \mathrm{g} / \mathrm{mL})$

SAM: Sideritis akmanii methanol extract, SAA: Sideritis akmanii acetone extract, BHT: Butylated hydroxytoluene and $\alpha$-tocopherol 


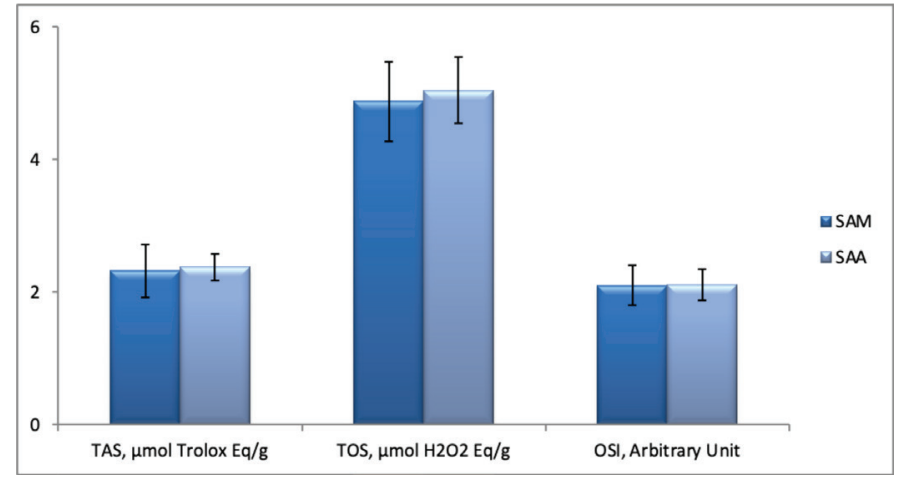

Figure 3. TAS, TOS and OSI data for Sideritis akmanii. The results are presented as mean \pm SD $(n=4)$

SAM: Sideritis akmanii methanol extract, SAA: Sideritis akmanii acetone extract, TAS: Total antioxidant status, TOS: Total oxidant status, OSI: Oxidative stress index, SD: Standard deviation

extracts. The acetone extract TOS level was higher compared to the methanol extract, however it was found that the OSI, which is an indicator of the oxidative stress, was similar for both extracts.

\section{Sideritis akmanii mineral substance content}

In a study that determined the bio-element content in endemic Sideritis species (S. germanico politana, S. galatica, and S. hispana), it was determined that the heavy metal concentrations in Sideritis species were within the limits for human consumption without health risks and Sideritis species indigenous to Turkey could be considered a significant source for certain nutritional elements such as iron and potassium. ${ }^{21}$

In this study, the mineral substance profile of S. akmanii species was also examined. As is the case with other Sideritis species, S. akmanii species was prominent with high $\mathrm{Mg}$ and $\mathrm{Al}$ concentrations, in addition to $\mathrm{Fe}$ and $\mathrm{K}$ content. Furthermore, $\mathrm{Zn}$, $\mathrm{Mn}$ and $\mathrm{Cu}$ concentrations in the antioxidant enzyme structure were also very high. However, since the concentration of Se element incorporated in the glutathione peroxidase structure was not within the measurable levels, it could not be recorded. Table 2 summarizes the mineral substance levels in S. akmanii species.

As shown in Table 3, Se, Be, and Co element concentrations were not within the detectable limits, so concentrations for these elements could not be determined. It was determined that all other minerals, which were identified as antioxidants, were observed at sufficient levels S. akmanii species, except Se.

\section{GC-MS analysis results}

S. akmanii collected from Afyonkarahisar province dry oil yield was determined as $0.13 \%$. Palmitic acid $(17.9 \%)$, myristic acid (11.0\%) and spathulenol (8.0\%) were found as the main components in the plant essential oil (Table 4).

The composition of Sideritis species volatile oil divided into 6 groups; rich in monoterpenes, rich in oxygenated monoterpenes, rich in sesquiterpenes, rich in oxygenated sesquiterpenes, rich in diterpenes and others. ${ }^{22}$ Additionally, high oil yield of plants obtained from the essential oil composition monoterpene rich,

\begin{tabular}{llll}
$\begin{array}{l}\text { Table 3. Mineral substance and concentrations of S. akmanii } \\
\text { Mineral } \\
\text { substance }\end{array}$ & $\begin{array}{l}\text { Concentration } \\
(\mathrm{ppm})\end{array}$ & $\begin{array}{l}\text { Mineral } \\
\text { substance }\end{array}$ & $\begin{array}{l}\text { Concentration } \\
(\mathrm{ppm})\end{array}$ \\
\hline $\mathrm{Al}$ & $891.64 \pm 46.78$ & $\mathrm{~K}$ & $1904.69 \pm 86.48$ \\
\hline $\mathrm{B}$ & $7.884 \pm 0.96$ & $\mathrm{Li}$ & $0.619 \pm 0.28$ \\
\hline $\mathrm{Ba}$ & $31.02 \pm 0.98$ & $\mathrm{Mg}$ & $907.26 \pm 35.96$ \\
\hline $\mathrm{Bi}$ & $3.634 \pm 0.64$ & $\mathrm{Mn}$ & $32.05 \pm 3.46$ \\
\hline $\mathrm{Ca}$ & $1344.5 \pm 92.5$ & $\mathrm{Na}$ & $461.68 \pm 28.59$ \\
\hline $\mathrm{Cr}$ & $2.13 \pm 0.17$ & $\mathrm{Ni}$ & $1.23 \pm 0.16$ \\
\hline $\mathrm{Cu}$ & $6.23 \pm 1.82$ & $\mathrm{~Pb}$ & $3.21 \pm 0.83$ \\
\hline $\mathrm{Fe}$ & $1264.37 \pm 26.75$ & $\mathrm{Zn}$ & $10.01 \pm 2.06$ \\
\hline
\end{tabular}

The results are presented as mean \pm SD $(n=4)$. SD: Standard deviation

Table 4. Essential oil composition of S. akmanii

No Compound

Relative percentage

(\%)

\begin{tabular}{|c|c|c|}
\hline 1. & $\beta$-Burbone & 0.5 \\
\hline 2. & $\beta$-Caryophyllen & 1.1 \\
\hline 3. & $\alpha$-Acoradiene & 1.0 \\
\hline 4. & Curcumen & 4.5 \\
\hline 5. & Caryophyllen oxide & 5.7 \\
\hline 6. & Hexahydrofarnesyl acetone & 1.5 \\
\hline 7. & Spatulenol & 8.0 \\
\hline 8. & Turmerol & 1.3 \\
\hline 9. & $\alpha$-Bisabolol & 1.5 \\
\hline 10. & 9-Geranyl- $\rho$-cymene & 3.1 \\
\hline 11. & Kaur-15-en & 0.6 \\
\hline 12. & Caryophylla-2(12),6-dien-5 $\beta$-ol & 1.3 \\
\hline 13. & Manoyl oxide & 1.3 \\
\hline 14. & Dodecanoic acid (Lauric acid) & 0.5 \\
\hline 15. & (E)-9-octadecen-1-ol (trans-elaidyl alcohol) & 0.7 \\
\hline 16. & Tetradecanoic acid (myristic acid) & 11.0 \\
\hline 17. & 8,12-epoxy-13-hydroxy-14-ene-labdien & 1.1 \\
\hline 18. & Pentadecanoic acid & 0.6 \\
\hline 19. & Hexadecanoic acid (palmitic acid) & 17.9 \\
\hline 20. & (Z)-Hexadecenoic acid (palmitoleic acid) & 1.2 \\
\hline 21. & (Z)-9-octadecenoik acid (oleic acid) & 2.2 \\
\hline
\end{tabular}

plants with low fat yield were found to be rich in sesquiterpene compounds. ${ }^{23}$ Studies conducted with Sideritis genus demonstrated that the plants contain terpenes, flavonoids, iridoids, coumarins, lignans, and sterols. Diterpen and flavonoid structures are found in almost all species. It was considered that the pharmacological activity of the species originate from 
these structures. While sesquiterpene and triterpene structures are uncommon in Sideritis species, diterpene structures are quite common. About 160 different diterpene species were found in these species. ${ }^{24}$ Especially in Mediterranean countries (Turkey, Greece and Italy), it was observed that Sideritis species contained kauri diterpenes. Kauren diterpene derivatives, namely, folios, idol, linearol, sideridiol and isolinearol were identified in the species. ${ }^{25-27}$

In our study, the presence of pinene component in $S$. akmanii volatile oil was not detected and the presence of sesquiterpenes such as $\beta$-caryophylen (1.1\%) caryophyllen oxide (5.7\%) $\alpha$-bisabolol (1.5\%) were determined. More entkauren diterpenes are obtained from the plants grown in the Eastern Mediterranean region. Because of this study, only kaur15-en diterpene was obtained.

\section{Enzyme inhibitory activities}

\section{Anti-ChE activity}

Alzheimer's disease (AD) is an age-related neurodegenerative disorder and the most common form of dementia in the elderly. ${ }^{28}$ AChE inhibitors are used for treating $A D$ and many researchers have attempted to identify novel AChE inhibitors from plant sources. ${ }^{29,30}$ In this study, the anti-ChE activity of $S$. akmanii was investigated for the first time. It was determined that acetone extract $(42.95 \% \pm 0.90 ; 217.37 \pm 0.81 \mathrm{mg}$ GALAEs/g) exhibited higher anti-ChE activity than methanol $(33.33 \% \pm 1.81$; $208.76 \pm 1.62 \mathrm{mg} \mathrm{GALAE} / \mathrm{g}$ ) (Table 5 ). It has been reported that essential oil components such as oxygenated monoterpene compounds are the main agents responsible for the effect of anti-Alzheimer. ${ }^{29}$ According to the GC-MS results, the fatty acid composition of $S$. akmanii contains terpene compounds such as $\beta$-caryophyllene and $\alpha$-bisabolol. It has been reported that phenolic acids such as ferulic acid and p-coumaric acid exhibits strong anti-ChE activity in extracts. ${ }^{31}$ Diterpenes isolated from Sideritis arguta showed no inhibition activity against acetylcholinesterase enzyme. ${ }^{32}$ When our results are evaluated, AChE inhibitory activity of $S$. amani extracts perform quite well compared to the standard used galantamine. The higher activity of acetone extract than methanol reveals how the solvent used can alter the enzyme activity.

\section{Antidiabetic activity}

One of the therapeutic approaches for reducing blood sugar is to delay glucose absorption by inhibition of carbohydrate hydrolysis enzymes such as $\alpha$-amylase and $\alpha$-glucosidase

Table 5. Acetyl choline esterase enzyme inhibition results of $S$. akmanii methanol and acetone extract

\begin{tabular}{lll} 
Extract & $\begin{array}{l}\text { AChE inhibition }(\mathrm{mg} \\
\text { GALAEs/g extract) }\end{array}$ & $\begin{array}{l}\text { AChE } \\
\text { inhibition (\%) }\end{array}$ \\
\hline SAM & $208.76 \pm 1.62$ & $33.33 \pm 1.81$ \\
\hline SAA & $217.37 \pm 0.81$ & $42.95 \pm 0.90$ \\
\hline Galantamine $(0.5 \mu \mathrm{mol} / \mathrm{mL})$ & - & $51.28 \pm 0.01$ \\
\hline
\end{tabular}

Values expressed are means \pm SD of four parallel measurements. GALAEs: Galantamine equivalents, AChE: Acetyl choline esterase, SAM: S. akmanii methanol extract, SAA: S. akmanii acetone extract in digestive organs. ${ }^{33}$ Therefore, studies to develop new pharmacological agents are related to $\alpha$-amylase and $\alpha$-glucosidase inhibition., ${ }^{5,3}$ It has been reported that some natural extract components containing phenolics, flavonoids and their glycosides exhibit $\alpha$-glucosidase inhibitory effect. Polyphenolic compounds in plants inhibit the activity of digestive enzymes due to their ability to bind proteins. ${ }^{35}$ Since these molecules have antioxidant effects, it is possible that the antioxidant and $\alpha$-glucosidase inhibitory properties are due to their polyphenolic content.

In this study, $\alpha$-amylase inhibition was high in methanol extract ( $53.62 \pm 1.85 \mathrm{mmol}$ ACEs/g extract) compared to acetone $(47.73 \pm 0.92 \mathrm{mmol}$ ACEs/g extract (Table 6). Additionally, when we examined the percent inhibition, it was found that the results were very close to the acarbose and results of the methanol and acetone extracts were close to each other. $\alpha$-Amylase inhibition value of the methanol extract of Sideritis galatica, $0.41 \pm 0.01 \mathrm{mmol} A C E s / g$, and the $\alpha$-glucosidase inhibition value was $1.68 \pm 0.28 \mathrm{mmol}$ ACEs/g. Simultaneously, Sideritis galactica petroleum ether and ethyl acetate extracts had higher $\alpha$-amylase and $\alpha$-glucosidase inhibition than methanol and water extracts. ${ }^{13}$ The relatively low inhibitory potential of Sideritis perfoliata extracts prepared with increasing polarity. ${ }^{36}$

The inhibition of amylase and glucosidase enzymes close to the acarbose standard may indicate that the plant has significant potential for treating type 2 diabetes. In conclusion, it can be concluded that the species S. akmanii, which has antioxidant properties, may be a promising pharmacological agent for treating diabetes.

\section{Tyrosinase inhibitory activity}

Tyrosinase contains copper and is involved in melanin biosynthesis.it is also an enzyme that catalyzes the oxidation of tyrosine to DOPA and DOPA kinona. ${ }^{36}$ Melanin plays an important role in protecting the skin from ionizing radiation such as ultraviolet. Tyrosinase has been researched for its use in the food industry along with cosmetics and agriculture for many years. Recently, its applications in the medical industry have gained considerable popularity because it affects protecting from pigmentation and other skin disorders such as vitiligo, malignant melanoma. ${ }^{37}$ Common tyrosinase inhibitors, such as hydroquinone, kojic acid and arbutin, have some adverse effects on human health. ${ }^{38}$

In this study, the tyrosinase inhibitory activity of S. akmanii was determined in vitro. Methanol $(4.24 \% \pm 0.146)$ and acetone extracts $(8.07 \% \pm 0.29)$ were observed to exhibit very low inhibition of the reference compound, $\alpha$-kojic acid $(86.34 \% \pm 1.46)$ (Table 7$)$. The antityrosinase effect of the methanol extract was $80.42 \pm 0.95 \mathrm{mg} \mathrm{KAE} / \mathrm{g}$ as the equivalent of the kojic acid, acetone extract was found as $105.42 \pm 1.91 \mathrm{mg}$ $\mathrm{KAE} / \mathrm{g}$ extracts. Our study is important because it is the first study on the tyrosinase enzyme inhibiting activity of S. akmanii. Different solvent extracts and different concentrations of the plant should be studied to determine the tyrosinase enzyme inhibition. 
Table 6. $\alpha$-Amylase and $\alpha$-glucosidase enzyme inhibition results of $S$. akmanii methanol and acetone extract

\begin{tabular}{lllll} 
Extract & $\begin{array}{l}\alpha \text {-Amylase inhibition } \\
\text { (mmol ACAEs/g } \\
\text { extract) }\end{array}$ & $\begin{array}{l}\alpha \text {-Amylase } \\
\text { inhibition }(\%)\end{array}$ & $\begin{array}{l}\alpha \text {-Glucosidase inhibition } \\
\text { (mmol ACAEs/g extract) }\end{array}$ & $\begin{array}{l}\alpha \text {-Glucosidase } \\
\text { inhibition (\%) }\end{array}$ \\
\hline SAM & $53.62 \pm 1.85$ & $45.39 \pm 0.22$ & $59.23 \pm 0.49$ & $76.82 \pm 0.09$ \\
\hline SAA & $47.73 \pm 0.92$ & $46.11 \pm 0.11$ & $62.37 \pm 0.98$ & $76.25 \pm 0.18$ \\
\hline Acarbose $(1 \mu \mathrm{mol} / \mathrm{mL})$ & - & $51.36 \pm 0.12$ & - & $85.81 \pm 2.45$ \\
\hline
\end{tabular}

Results expressed are means \pm SD of four parallel measurements. ACAE: Acarbose equivalent, SAM: S. akmanii methanol extract, SAA: S. akmanii acetone extract, SD: Standard deviation

Table 7. Tyrosinase enzyme inhibition results of Sideritis akmanii methanol and acetone extract

\begin{tabular}{lll} 
Extract & $\begin{array}{l}\text { Tyrosinase } \\
\text { inhibition }(\mathrm{mg} \\
\mathrm{KAEs} / \mathrm{g} \text { ekstre })\end{array}$ & $\begin{array}{l}\text { Tyrosinase } \\
\text { inhibition } \\
(\%)\end{array}$ \\
\hline SAM & $80.42 \pm 0.95$ & $4.24 \pm 0.146$ \\
\hline SAA & $105.42 \pm 1.91$ & $8.07 \pm 0.29$ \\
\hline Kojic acid $(2 \mu \mathrm{mol} / \mathrm{mL})$ & - & $86.34 \pm 1.46$ \\
\hline
\end{tabular}

Values expressed are means \pm SD of four parallel measurements. KAEs: Kojic acid equivalent, SAM: Sideritis akmanii methanol extract, SAA: Sideritis akmanii acetone extract, SD: Standard deviation

\section{CONCLUSION}

In conclusion, it can be suggested that Sideritis akmanii methanol, and acetone extracts possess antioxidant effects due to their phenolic substance content. The determined TAS, TOS and OSI values also support this suggestion. It was found that the radical scavenging activities in the methanol extract was similar to that of the synthetic antioxidant BHT and higher than that of the acetone extract. These findings indicated that the species, especially the methanol extract had antiradical effects. The mineral content of the species included important minerals ( $\mathrm{Mn}, \mathrm{Zn}, \mathrm{Fe}, \mathrm{Cu}$ ) within the antioxidant enzyme structure. Due to the adverse effects of synthetic antioxidants, studies on natural antioxidant sources have increased during recent years. This is the first study to investigate the chemical composition and enzyme inhibitory potential of S. akmanii. As a result, methanol and acetone extracts of S. akmanii have enzyme inhibition activity and the data obtained will contribute to the search for new alternative drugs to be used for treating diseases such as diabetes, Alzheimer's and Parkinson's. Identification of antioxidant activities and active components in plants, identification and purification of their structures constitute the first step in these studies. Due to their total phenolic content, their effect on the radicals, TAS, TOS, OSI values and their mineral content, it is considered that $S$. akmanii could be used in phytotherapeutical studies and particularly in studies on antioxidant effect.

\section{ACKNOWLEDGMENTS}

This study was supported by the Scientific Research Projects Commission of the Afyon Kocatepe University, with the ID numbers 18. KARIYER.79 and 15.FEN.BIL.41.
Conflict of interest: No conflict of interest was declared by the authors. The authors are solely responsible for the content and writing of this paper.

\section{REFERENCES}

1. Gumuscu A, Tugay O, Kan Y. Comparison of essential oil compositions of some natural and cultivated endemic Sideritis species. Adv Environ Biol. 2011;5:222-226.

2. Chauhan PS, Puri N, Sharma P, Gupta N. Mannanases: microbial sources, production, properties and potential biotechnological applications. Appl Microbiol Biotechnol. 2012;93:1817-1830.

3. Etxeberria U, de la Garza AL, Campión J, Martínez JA, Milagro Fl. Antidiabetic effects of natural plant extracts via inhibition of carbohydrate hydrolysis enzymes with emphasis on pancreatic alpha amylase. Expert Opin Ther Targets. 2012;16:269-297.

4. Kim YJ, Uyama H. Tyrosinase inhibitors from natural and synthetic sources: structure, inhibition mechanism and perspective for the future. Cell Mol Life Sci. 2005;62:1707-1723.

5. Murray AP, Faraoni MB, Castro MJ, Alza NP, Cavallaro V. Natural AChE inhibitors from plants and their contribution to Alzheimer's disease therapy. Curr Neuropharmacol. 2013;11:388-413.

6. Gülçin I, Beydemir Ș, Şat IG, Küfrevioğlu Ö. Evaluation of antioxidant activity of cornelian cherry (Cornus mas L.). Acta Aliment. 2005;34:193202.

7. Dikilitas M, Guldur ME, Deryaoglu A, Erel O. Antioxidant and oxidant levels of pepper (Capsicum annuum cv. 'Charlee') infected with pepper mild mottle virus. Not Bot Horti Agrobo. 2011;39:58-63.

8. Aksoy L, Sözbilir NB. Trace and major element levels in rats after oral administration of diesel and biodiesel derived from opium poppy (Papaver somniferum L.) seeds. Toxicol Ind Health. 2015;31:890-897.

9. Blois MS. Antioxidant determinations by the use of a stable free radical. Nature. 1958;26:1199-1200.

10. Slinkard K, Singleton VL. Total phenol analysis: automation and comparison with manual methods. Am J Enol Viticult. 1977;28:49-55.

11. Ellman GL, Courtney KD, Andres V Jr, Feather-Stone RM. A new and rapid colorimetric determination of acetylcholinesterase activity. Biochem Pharmacol. 1961;7:88-95.

12. Yang XW, Huang MZ, Jin YS, Sun LN, Song Y, Chen HS. Phenolics from Bidens bipinnata and their amylase inhibitory properties. Fitoterapia. 201283:1169-1175.

13. Zengin G, Sarikurkcu C, Aktumsek A, Ceylan R, Ceylan O. A comprehensive study on phytochemical characterization of Haplophyllum myrtifolium Boiss. endemic to Turkey and its inhibitory 
potential against key enzymes involved in Alzheimer, skin diseases and type II diabetes. Ind Crops Prod. 2014;53:244-251.

14. Masuda T, Yamashita D, Takeda Y, Yonemori S. Screening for tyrosinase inhibitors among extracts of seashore plants and identification of potent inhibitors from Garcinia subelliptica. Biosci Biotechnol Biochem. 200569:197-201.

15. Bravo L. Polyphenols: chemistry, dietary sources, metabolism, and nutritional significance. Nutr Rev. 1998;56:317-333.

16. Bondì ML, Bruno M, Piozzi F, Husnu Can Baser K, Simmonds MS. Diversity and antifeedant activity of diterpenes from Turkish species of Sideritis. Biochem Syst Ecol. 2000;28:299-303.

17. Şahin FP, Ezer N, Çalış İ. Terpenic and phenolic compounds from Sideritis stricta. Turk J Chem. 2006;30:495-504.

18. Tunalier Z, Kosar M, Ozturk N, Baser KHC, Duman H, Kirimer N. Antioxidant properties and phenolic composition of Sideritis species. Chem Nat Compd. 2004;40:206-210.

19. Sagdic O, Aksoy A, Ozkan G, Ekici L, Albayrak S. Biological activities of the extracts of two endemic Sideritis species in Turkey. Innov Food Sci Emerg. 2008;9:80-84.

20. Ku YS, Wong JW, Mui Z, Liu X, Hui JH, Chan TF, Lam HM. Small RNAs in plant responses to abiotic stresses: regulatory roles and study methods. int J Mol Sci. 2015;16:24532-24554.

21. Korkmaz K, Kara SM, Özkutlu F, Akgün M, Coşge Şenkal B. Profile of heavy metal and nutrient elements in some sideritis species. Int $J$ Pharm. 2017;51:209-212.

22. Baser KHC. Aromatic biodiversity among the flowering plant taxa of Turkey. Pure Appl Chem. 2002;74:527-545.

23. Kirimer N, Baser KHC, Demirci B, Duman H. Essential oils of Sideritis species of Turkey belonging to the section Empedoclia. Chem Nat Compd. 2004; 40:19-23.

24. González-Burgos E, Carretero ME, Gómez-Serranillos MP. Sideritis spp.: uses, chemical composition and pharmacological activities--a review. J Ethnopharmacol. 2011;135:209-225.

25. Fraga BM, Hernandez MG, Diaz CE. On the ent-kaurene diterpenes from Sideritis athoa. Nat Prod Res. 2003;17:141-144.

26. Kilic T. Isolation and biological activity of new and known isolation and biological activity of new and known diterpenoids from Sideritis stricta Boiss. \& Heldr. Molecules. 2006;11:257-262.

27. Topçu G, Gören AC, Yildiz YK, Tümen G. Ent-kaurene diterpenes from Sideritis athoa. Nat Prod Lett. 1999:14:123-129.
28. Jukic M, Politeo O, Maksimovic M, Milos M, Milos M. In vitro acetylcholinesterase inhibitory properties of thymol, carvacrol and their derivatives thymoquinone and thymohydroquinone. Phytother Res. 2007;21:259-261.

29. Bahadori MB, Zengin G, Bahadori S, Maggi F, Dinparast L. Chemical composition of essential oil, antioxidant, antidiabetic, anti-obesity, and neuroprotective properties of Prangos gaubae. Nat Prod Commun. 2017;12:1945-1948.

30. Giacobini E. Cholinesterase inhibitors: new roles and therapeutic alternatives. Pharmacol Res. 2004;50:433-440.

31. Movahhedina N, Zengin G, Bahadori MB, Sarikurkcu C, Bahadoria S. Dinparast L. Ajuga chamaecistus subsp. scoparia (Boiss.) rech.f.: a new source of phytochemicals for antidiabetic, skin-care, and neuroprotective uses. Ind Crops Prod. 2016;94:89-96.

32. Szwajgier D, Borowiec K. Phenolic acids from malt are efficient acetylcholinesterase and butyrylcholinesterase inhibitors. J I Brewing. 2012;118:40-48.

33. Ertaş A, Oztürk M, Boğa M, Topçu G. Antioxidant and anticholinesterase activity evaluation of ent-kaurane diterpenoids from Sideritis arguta. $J$ Nat Prod. 2009;72:500-502.

34. McCue P, Kwon YI, Shetty K. Anti-diabetic and anti-hypertensive potential of sprouted and solid-state bioprocessed soybean. Asia Pac J Clin Nutr. 2005;14:145-152.

35. Johnston BD, Ghavami A, Jensen MT, Svensson B, Pinto BM. Synthesis of selenium analogues of the naturally occurring glycosidase inhibitor salacinol and their evaluation as glycosidase inhibitors. J Am Chem Soc. 2002;124:8245-8250.

36. Loizzo MR, Saab AM, Tundis R, Menichini F, Bonesi M, Piccolo V, Statti GA, de Cindio B, Houghton PJ, Menichini F. In vitro inhibitory activities of plants used in Lebanon traditional medicine against angiotensin converting enzyme (ACE) and digestive enzymes related to diabetes. $J$ Ethnopharmacol. 2008;119:109-116.

37. Souza PM, Elias ST, Simeoni LA, de Paula JE, Gomes SM, Guerra EN, Fonseca YM, Silva EC, Silveira D, Magalhães PO. Plants from Brazilian Cerrado with potent tyrosinase inhibitory activity. PLoS One. 2012;7:e48589.

38. Maeda K, Fukuda M. In vitro effectiveness of several whitening cosmetic components in human melanocytes. J Soc Cosmet Chem. 1991;42:361368. 